\title{
THE EFFECTIVENESS OF THE USE OF THE ANDROID-BASED CAROM GAMES COMIC INTEGRATED TO DISCOVERY LEARNING IN IMPROVING CRITICAL THINKING AND MATHEMATICAL REPRESENTATION ABILITIES
}

\author{
Mega Septiana Ika Rahayu iD, Heru Kuswanto iD \\ Universitas Negeri Yogyakarta (Indonesia) \\ megaseptiana30@gmail.com, berukus61@uny.ac.id
}

Received November 2020

Accepted March 2021

\section{Abstract}

This research aims to reveal the effectiveness of the use of the Android-based carom games comic integrated to discovery learning (MIKIMOM) in improving critical thinking and mathematical representation in the teaching of physics. It is quantitative research with the quasi experimental research design. It was conducted in two phases, with the first phase for empirical try out of the test and second phase for the application of MIKIMOM to reveal the effectiveness of the developed media in teaching. The empirical try out was conducted to 261 grade XI MIA students. The application of the media was conducted to 32 students of grade X MIA 3 State Senior High School (SSHS) 2 Banguntapan as an experimental class using MIKIMOM and 32 students of grade X MIA 4 State Senior High School (SSHS) 2 Banguntapan as an experimental class using the Powerpoint (PPT) media. The data were collected using a critical thinking and mathematical representation test which was valid and reliable according to the empirical testing. The data were analyzed using the QUEST program to see the validity and reliability of the test items, and the MANOVA test to see the effectiveness of the media. The research finding shows that MIKIMOM is effective in improving the critical thinking and mathematical representation of the students with the scores of 0.287 (large effect size) and 0.179 (medium effect size).

Keywords - Critical thinking, mathematical representation, MIKIMOM.

\section{To cite this article:}

Rahayu, M.S.I., \& Kuswanto, H. (2021). The effectiveness of the use of the android-based carom games comic integrated to discovery learning in improving critical thinking and mathematical representation abilities. Journal of Technology and Science Education, 11(2), 270-283. https://doi.org/10.3926/jotse.1151

\section{Introduction}

Critical thinking is considered as an important component in the activities of a student as a scientist (Viennot \& Nicolas, 2018; Wahyudi, Verawati, Ayub \& Prayogi, 2019). This is due to the fact that critical thinking will encourage students to reason, discuss, express their reason, and draw conclusions. Critical thinking enables one to distinguish facts from opinions and to evaluate and assess the truth of available evidence (El Soufi \& See, 2019). However, the critical thinking ability of students is low (Puspita, Kaniawati \& Suwarma, 2017; Sutrisno, 
Handayanto, Supriyana \& Laksmisari, 2018). They still find it difficult to comprehend all materials and they can comprehend very little about certain concepts in every topic of physics teaching (Karim, Saepuzaman \& Sriyansyah, 2015; Budiarti, Rusnayati, Siahaan \& Wijaya, 2018) and therefore, they have lacks of patterns. The difficulties in understanding the materials include the difficulties in understanding basic concepts, distinguishing symbols, and relating one concept with other concepts (Yuliati, Fauziah \& Hidayat, 2018). In addition, the students cannot understand concepts and do analyses to solve problems because they are often faced with problems which require mathematic equation so that they also need to have mathematical representation ability (Siswanto, Susantini \& Jatmiko, 2012; Bego, Chastain, Pyles \& DeCaro, 2018).

Mathematical representation is a way to show a condition using a mathematical model (Park \& Choi, 2013; Purwadi, Sudiarta \& Suparta, 2019). It is used to observe prediction and assumption of a problem using reasoning skill so that the students can understand, make, and evaluate assumptions and arguments mathematically and systematically (Cartrette \& Bodner, 2010; Nor'ain Mohd \& Chinnappan, 2016; Doran, 2017). In general, mathematical representation takes the form of equation and formula (Namdar \& Shen, 2017) and the combination of mathematical symbols and structure which use numbers, variables, and equation (Jaccard \& Jacoby, 2010; Priyadi, Kuswanto \& Sumarna, 2020). This equation in physics is called physics language (Docktor \& Mestre, 2014). The equation can be used for determining the solution to a problem through the manipulation of the symbol of numbers of an identified variable so that it can be used as a proof of a solution process (Kuo, Hull, Gupta \& Elby, 2012; Hau, Marwoto \& Putra, 2018). In other words, mathematical representation is a mathematical equation which reveals a concept (Redish \& Kuo, 2015). It can change an abstract concept to become concrete by using equations or graphs, so that teaching becomes more meaningful (Supandi, Waluya, Rochmad, Suyitno \& Dewi, 2018). However, the students' representation ability is still low. They find difficulties in mathematic basic operational concepts, placing positive and negative symbols in numbers that results in wrong calculation (Jitendra, Nelson, Pulles, Kiss \& Houseworth, 2016), using arithmetic symbols in problem solution (Sari, Dahrim \& Rosjanuardi, 2018), and determining variables for making equations (Redish \& Kuo, 2015).

Based on the above analysis, there needs for learning that can help students improve their critical thinking and mathematical representation. Mathematical representation and critical thinking abilities can be improved in many ways, one of which is by applying a correct model and media. The teaching model which can be applied is discovery learning (Minarni, Napitupulu \& Husein, 2016).

Discovery learning is a teaching model for active students because they are obliged to discover their own concept with the help of the provided stimuli. The experience in discovering and investigating by themselves will make their memory of a concept long lasting and not easily forgotten (Hosnan, 2014; Martaida, Bukit \& Ginting, 2017). The use of discovery learning facilitates the students' critical thinking in teaching because this teaching model has the steps which can encourage them to interact and make ideas based on observation, experiment, and enquire (Sulistiani, Waluya \& Masrukan, 2018). The discovery learning steps in teaching include making stimuli, identifying problems, collecting data, verifying data, and drawing conclusion (In'am \& Hajar, 2017). The use of discovery learning can also bring up curiosity to solve problems well and to think critically (Ramdhani, Usodo \& Subanti, 2017). Curiosity affects the motivation to learn so that students will be motivated to find the solution to an existing problem by thinking critically (Isnaningsih \& Bimo, 2013). This kind of teaching when collaborated with teaching media can result in interesting condition, make students more active, and improve their motivation to learn so that their learning achievement will improve (Permatasari, Soegiyanto \& Usodo, 2019)

One of the media which can be used to support teaching representation which is interesting and can facilitate students to learn is Android-based physics comics (Irwandani \& Juariah, 2016; Rahayu \& Kuswanto, 2020). Comic is a combination of pictures and texts which can increase the effectiveness of education because it is a teaching aid which can convey information effectively and efficiently (Guérin, Rigaud, Bertet \& Revel, 2017; Mutia, Gani \& Syukri, 2020). Learning through comics enables students to express new ideas so that it is not boring (Cahyono, Isnandar \& Usodo, 2019). Android-based media can also be used for learning physics anytime and anywhere (Raras \& Kuswanto, 2019; Maghfiroh, Kuswanto 
\& Susetyo, 2020). They can replace packaged books because they already contain illustrating video, materials, examples of test items, discussion, and practice test (Nikmah, Haroky, Jumadi, Wilujeng \& Kuswanto, 2019). They can be integrated into a teaching model or approach (Rahayu \& Kuswanto, 2020). Besides, they will also facilitate learning processes, especially in actualizing abstract concepts through concrete everyday lives (Yulianti et al., 2016; Rina, 2020) such as carom games.

The car om game is one of the traditional games which use a square table having one hole in each diagonal corner (Atmaja, Jonemaro \& Arwani, 2017). This game applies many strategies and analyses of the condition to put carom pieces (pucks) in pockets accurately and win the game (Asisningtyas \& Suryanti, 2017). In fact, some conditions and events in carom games are related to physics teaching materials, i.e. the concept of momentum and impulse. Therefore, this research applies an Android-based carom games comic integrated to discovery learning (MIKIMOM = comic impulse momentum) and reveals it is the effectiveness in improving critical thinking and mathematical representation abilities in the teaching of physics.

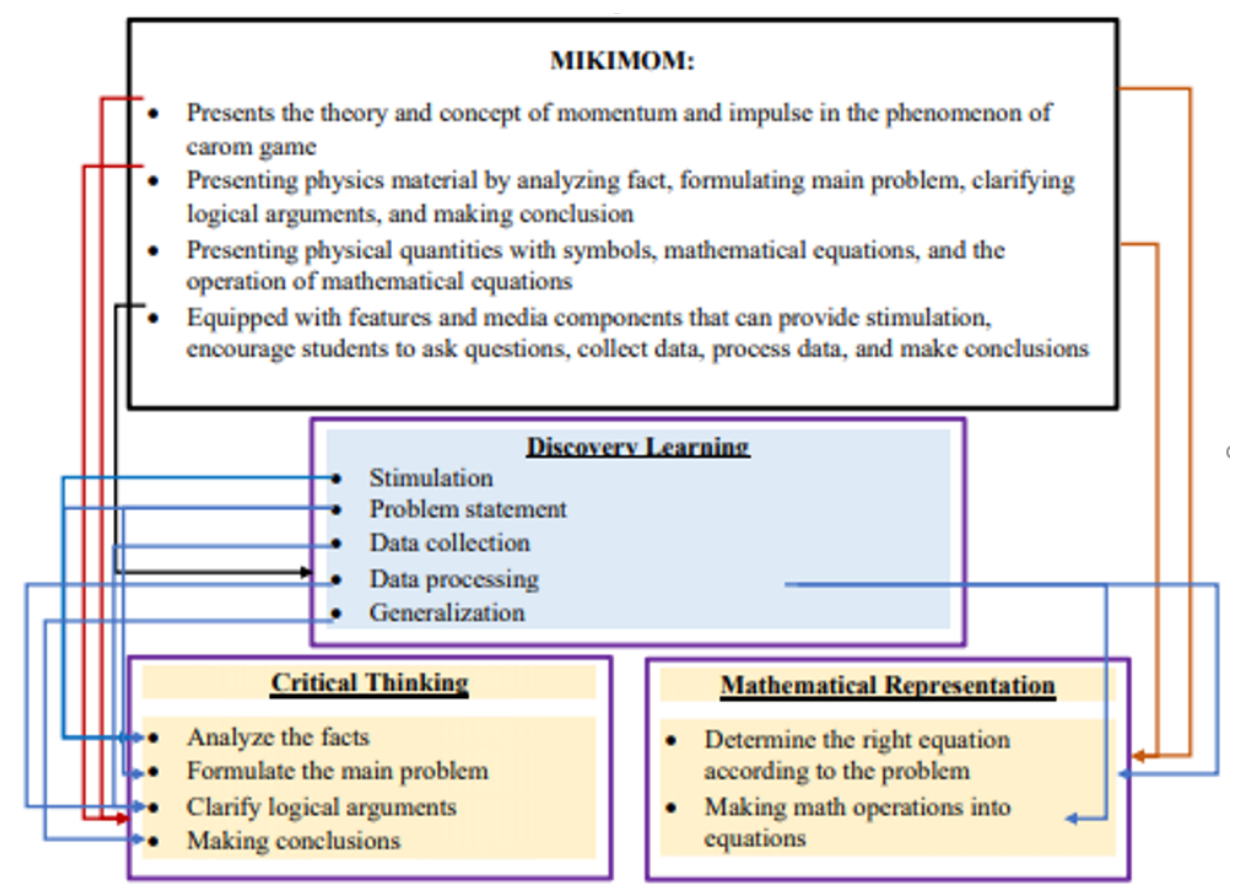

Figure 1. Conceptualization of MIKIMOM as a learning media that integrated with discovery learning to improve critical thinking and mathematical representation abilities

\section{Research Method}

\subsection{Type of Research}

This research is a quantitative study with the quasi experimental research design. It uses two classes: experimental class and control class. The experimental class is the class that is given treatment of the use of an Android-based carom games comic integrated to discovery learning (MIKIMOM), while the control class is the class taught by using the power points (PPT). PPT is used in the control class because PPT is a conventional learning media that is often used by physics teachers at State Senior High School (SSHS) 2 Banguntapan to delivering physics material. The research design can be seen in Table 1.

\begin{tabular}{|l|c|c|c|c|c|}
\hline \multirow{2}{*}{ Group } & \multicolumn{2}{c|}{ Pretest } & \multicolumn{2}{c|}{ Treatment } & \multicolumn{2}{c|}{ Posttest } \\
\cline { 2 - 6 } & $\mathbf{Y}_{1}$ & $\mathbf{Y}_{\mathbf{2}}$ & & $\mathrm{T}_{2}$ & $\mathrm{~T}_{2}$ \\
\hline Experimental Class & $\mathrm{T}_{1}$ & $\mathrm{~T}_{1}$ & $\mathrm{X}_{1}$ & $\mathrm{~T}_{2}$ & $\mathrm{~T}_{2}$ \\
\hline Control Class & $\mathrm{T}_{1}$ & $\mathrm{~T}_{1}$ & $\mathrm{X}_{2}$ & & \\
\hline
\end{tabular}

Table 1. Research design 


\section{Notes}

T1: Pretest

T2: Posttest

Y1: Critical thinking

Y2: Mathematical representation

X1: Application of Android-based carom games comic integrated to discovery learning (MIKIMOM)

X2: Physics teaching by using PPT

\subsection{Research Sample}

Administering the critical thinking and mathematical representation ability test in the materials about momentum and impulse to 261 grade XI students aiming at revealing the feasibility of the test in terms of validity and reliability. The students consist of those of State Senior High School (SSHS) 1 Plered (two classes), SSHS 2 Banguntapan (two classes), SSHS 1 Ngemplak (two classes), SSHS 1 Ngaglik (three classes), and SHS Bina Umat (two classes). All of the students undertook the momentum and impulse materials when they were in grade X. Experiment MIKIMOM at SSHS 2 Banguntapan aiming at revealing the effectiveness of the comic in improving critical thinking and mathematical representation abilities. The population for testing the effectiveness of MIKIMOM was 180 students of grade $\mathrm{X}$ at SSHS 2 Banguntapan. The sample selection was carried out using the cluster random sampling technique so that the experimental class was obtained as many as 32 students MIA 3 and the control class as many as 32 students X MIA 4. Students as the research sample consisted of male and female with the average of students being 15-16 years old, students come from medium socio-economic conditions so that all of students have android as their source and learning media. Testing the effectiveness of comics is by using a pretest and posttest with a distance of giving questions for two weeks (two meetings).

\subsection{Research Instrument and Procedure}

The instruments used in this research consist of a teaching instrument and data collecting instrument. The teaching instrument is in the form of lesson plans, MIKIMOM, and PPT. The data collecting instrument is an essay test of critical thinking and mathematical representation abilities in momentumimpulse materials, each of which consists of four items as shown in Table 2 below.

\begin{tabular}{|c|c|c|c|}
\hline $\begin{array}{c}\text { Basic } \\
\text { competence }\end{array}$ & $\begin{array}{l}\text { Indicators of critical } \\
\text { thinking ability }\end{array}$ & Item no & Indicators of test items \\
\hline \multirow{4}{*}{$\begin{array}{l}\text { Applying the } \\
\text { concept of impulse } \\
\text { and momentum, as } \\
\text { well as Momentum } \\
\text { Immunity Law in } \\
\text { everyday life }\end{array}$} & \multirow{4}{*}{$\begin{array}{l}\text { Analyzing facts } \\
\text { Formulating problems } \\
\text { Clarifying logical } \\
\text { arguments } \\
\text { Drawing conclusions }\end{array}$} & 1 & $\begin{array}{l}\text { Presented with a description of a child kicking a wooden } \\
\text { table and a sofa of a different material so that he } \\
\text { experiences different pains, the students can analyze facts, } \\
\text { formulate problems, clarify logical arguments, and draw } \\
\text { conclusion based of the concept of impulse in the event. }\end{array}$ \\
\hline & & 2 & $\begin{array}{l}\text { Presented with a description of a teacher throwing a ball at } \\
\text { students and then giving alternatives so that the students } \\
\text { can catch the ball easily, students can analyze facts, } \\
\text { formulate problems, clarify logical arguments, and draw } \\
\text { conclusion based of the concept of impulse in the event. }\end{array}$ \\
\hline & & 3 & $\begin{array}{l}\text { Presented with a description and picture of stationary } \\
\text { carom pieces (pucks) which are then struck with a certain } \\
\text { strength and interval, students can analyze facts, formulate } \\
\text { problems, clarify logical arguments, and draw conclusion } \\
\text { on the extent of the change occurring to the pucks. }\end{array}$ \\
\hline & & 4 & $\begin{array}{l}\text { Presented with a description of colliding pucks which } \\
\text { then move with different directions and speeds after } \\
\text { the collision, students can analyze facts, formulate } \\
\text { problems, clarify logical arguments, and draw } \\
\text { conclusion on the type of collision that has occurred. }\end{array}$ \\
\hline
\end{tabular}

Table 2. Indicators of critical thinking in the topic of momentum and impulse 


\begin{tabular}{|c|c|c|c|}
\hline $\begin{array}{c}\text { Basic } \\
\text { competence }\end{array}$ & $\begin{array}{l}\text { Indicators of } \\
\text { mathematical } \\
\text { representation }\end{array}$ & Item no & Indicators of test items \\
\hline \multirow{4}{*}{$\begin{array}{l}\text { Applying the } \\
\text { concept of impulse } \\
\text { and momentum, as } \\
\text { well as Momentum } \\
\text { Immunity Law in } \\
\text { everyday life }\end{array}$} & $\begin{array}{l}\text { Determining a correct } \\
\text { equation according to a } \\
\text { problem }\end{array}$ & 1 & $\begin{array}{l}\text { Presented with a description of two children striking } \\
\text { the same puck but with different speeds, students can } \\
\text { determine a correct equation for the amount of } \\
\text { momentum of each child. }\end{array}$ \\
\hline & $\begin{array}{l}\text { Doing mathematical } \\
\text { operation into an } \\
\text { equation }\end{array}$ & 2 & $\begin{array}{l}\text { Presented with a description of a colliding striker with } \\
\text { stationary target pucks, students can determine the } \\
\text { speed of the striker after the collision. }\end{array}$ \\
\hline & $\begin{array}{l}\text { Doing mathematical } \\
\text { operation into an } \\
\text { equation }\end{array}$ & 3 & $\begin{array}{l}\text { Presented with a description of a pingpong ball falling } \\
\text { from a certain height and bouncing on the floor, } \\
\text { students can determine the restitution of the bounce. }\end{array}$ \\
\hline & $\begin{array}{l}\text { Determining a correct } \\
\text { equation based on a } \\
\text { problem }\end{array}$ & 4 & $\begin{array}{l}\text { Presented with a description of a penalty kick, students } \\
\text { can determine the equation of the duration of the foot } \\
\text { touching the ball. }\end{array}$ \\
\hline
\end{tabular}

Table 3. Indicators of mathematical representation in the topic of momentum and impulse

This study uses the quasi experimental research design. The following is the procedure taken, as shown in Figure 2.

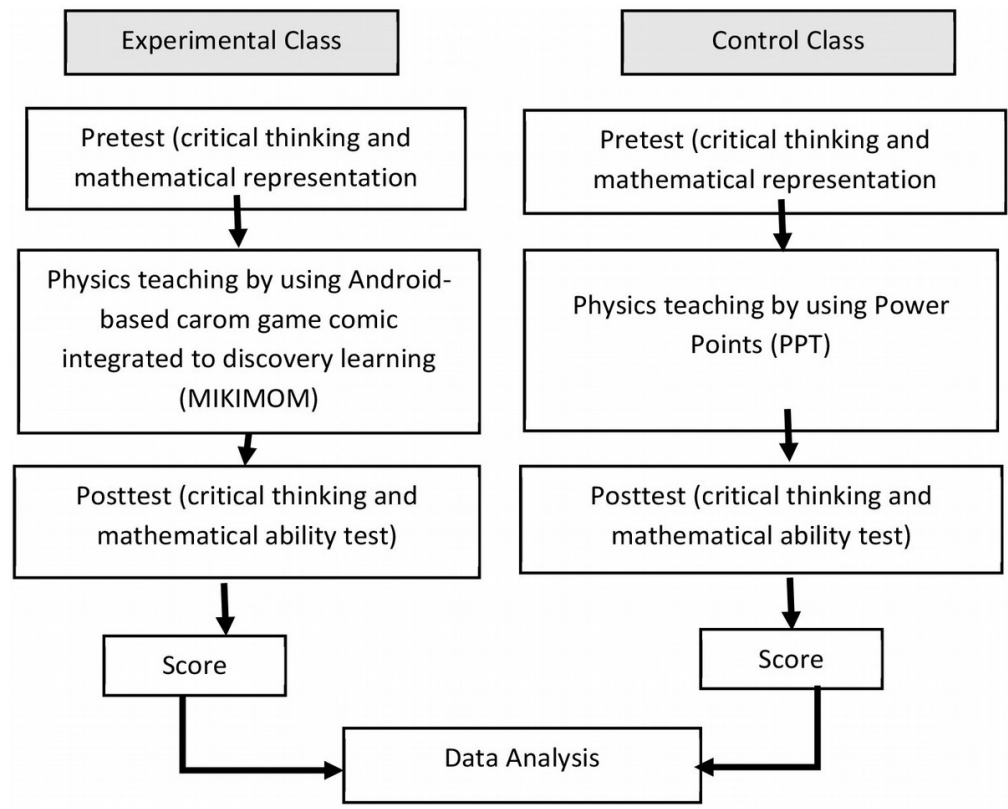

Figure 2. Research implementation scheme

\subsection{Data Analysis}

The analysis of the data on the test item feasibility was conducted using the QUEST program in order to reveal the item fitness (reliability and validity) as the requirement for the items to be used. The item reliability can be known from the summary of item estimates and summary of case estimates in the QUEST program output ranging from 0.6 to 0.8 , while the item validity can be known from the Infit Mean Square (INFIT MNSQ) which ranges from 0.77 to 1.30 , where an item is considered fit to the PCM model (Adam \& Kho, 1996) and item difficulty ranges from -2.0 to +2.0 (Hambleton, Swaminathan \& Rogers, 1991).

The analysis of the test items to see the improvement in critical thinking and mathematical representation abilities was conducted using the equation (Meltzer, 2002). 


$$
\text { Gain score }(g)=\frac{\bar{x} \text { posttest }-\bar{x} \text { pretest }}{x-\bar{x} \text { pretest }}
$$

If gain score $(\mathrm{g}) \geq 0,7$ then it is in the high category, if $0,7>(\mathrm{g}) \geq 0,3$ then it is in medium category, and if gain score $(\mathrm{g})<0,3$ then it is in the low category. Furthermore, revealing the effectiveness of the use of MIKIMOM used the statistical analysis applying the MANOVA test applying IBM SPSS. The first decision was made based on the output of SPSS on Hotelling Trace. The higher the score on Hotelling Trace the bigger the effect of the media. Revealing the effect size of MIKIMOM on the improvement of the students' critical thinking and mathematical representation abilities was conducted through the analysis of the effect size using multivariate GLM (General Linear Model). The GLM output in the form of eta square was converted into the value of Cohen's $\mathrm{f}$ so as to result in the effect size. The value of the effect size can be calculated with the equation (Cohen, 1988).

$$
f=\sqrt{\frac{\eta^{2}}{1-\eta^{2}}}
$$

\begin{tabular}{|c|c|}
\hline Cohen's $\mathbf{f}$ & Interpretation \\
\hline $0.0 \leq \mathrm{f}<0.10$ & Small Effect Size \\
\hline $0.10 \leq \mathrm{f}<0.25$ & Medium Effect Size \\
\hline $0.25 \leq \mathrm{f}<0.4$ & Large Effect Size \\
\hline $0.4 \leq \mathrm{f}$ & Very Large Effect Size \\
\hline
\end{tabular}

Table 4. Interpretation of Cohen's value

However, prior to the analysis of MANOVA statistics, there needed to be the statistic prerequisite analysis. The prerequisite analysis consisted of the multivariate normality analysis using Shapiro-Wilk, correlation analysis using Pearson Correlation, and homogeneity analysis using Box's M test.

\section{Findings and Discussion}

\subsection{Reliability and Validity of Critical Thinking and Mathematical Representation Ability Test}

The reliability of the critical thinking and mathematical representation ability test based on the QUEST output is good. The reliability coefficient is shown in the value of the summary of item estimates and summary of case estimates which ranges from 0.6 to 0.8 as shown in Table 5.

All of the test items are not only reliable but also valid because they are fit to PCM. This can be seen in the value of the infit mean square which ranges from 0.70 to 1.30 and falls into the valid category, as shown in Figures 3 and 4.

\begin{tabular}{|c|l|r|r|}
\hline No & Items tested & Summary of item estimate & Summary of case estimate \\
\hline 1 & Critical thinking ability & 0.81 & 0.69 \\
\hline 2 & Mathematical representation ability & 0.79 & 0.67 \\
\hline
\end{tabular}

\begin{tabular}{|c|c|c|c|c|c|c|c|}
\hline \multicolumn{8}{|l|}{ INFIT } \\
\hline MNSQ & .56 & .63 & .71 & .83 & 1.00 & 1.20 & 1.40 \\
\hline-------- & & & & ++- & --+- & ----+- & ----+ \\
\hline 1 item 1 & & & & & I & $*$ & . \\
\hline 2 item 2 & & & & * & I & & . \\
\hline 3 item 3 & & & & & I & $*$ & . \\
\hline 4 item 4 & & & & & I & & . \\
\hline
\end{tabular}

Table 5. Result of the analysis of the reliability of critical thinking and mathematical representation ability test items

Figure 3. Result of analysis of item fitness of critical thinking ability test items 
Based on the "it.out" of QUEST which aims to reveal the fitness of each item to IRT, all of the test items can be used for the assessment instrument, as shown in Table 6 .

Therefore, the items of the essay test in both critical thinking ability and mathematical representation ability are valid and reliable, and they can be used for assessing the improvement in the students' critical thinking and mathematical representation abilities.

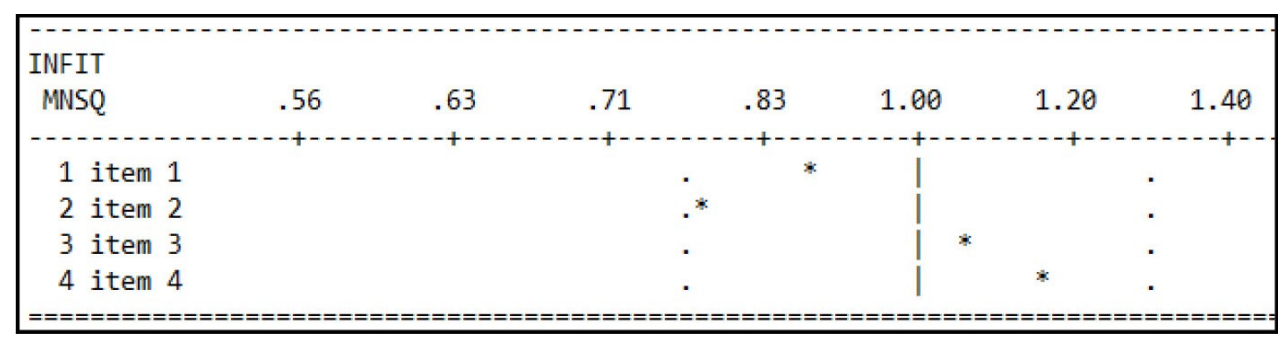

Figure 4. Result of analysis of item fitness of mathematical representation ability

\begin{tabular}{|l|l|r|r|r|r|r|c|c|}
\hline \multirow{4}{*}{ Items } & $\begin{array}{c}\text { Item } \\
\text { name }\end{array}$ & $\begin{array}{c}\text { INFIT } \\
\text { MNSQ }\end{array}$ & Criteria & OUFIT t & Criteria & DIFFCLTY & Criteria & $\begin{array}{c}\text { Item } \\
\text { quality }\end{array}$ \\
\hline \multirow{2}{*}{$\begin{array}{l}\text { Critical } \\
\text { thinking }\end{array}$} & Item 1 & 1.17 & Fit & 1.6 & Valid & -0.80 & Medium & Good \\
\cline { 2 - 9 } & Item 2 & 0.85 & Fit & -1.8 & Valid & -0.23 & Medium & Good \\
\cline { 2 - 9 } & Item 3 & 1.10 & Fit & 0.6 & Valid & 0.35 & Medium & Good \\
\cline { 2 - 9 } & Item 4 & 0.79 & Fit & -2.6 & Valid & 0.68 & Medium & Good \\
\hline \multirow{2}{*}{$\begin{array}{l}\text { Mathematical } \\
\text { representation }\end{array}$} & Item 1 & 0.88 & Fit & -1.4 & Valid & -0.18 & Medium & Good \\
\cline { 2 - 10 } & Item 2 & 0.78 & Fit & -2.3 & Valid & 0.69 & Medium & Good \\
\cline { 2 - 9 } & Item 3 & 1.06 & Fit & 0.2 & Valid & 0.28 & Medium & Good \\
\cline { 2 - 9 } & Item 4 & 0.16 & Fit & 1.8 & Valid & -0.79 & Medium & Good \\
\hline
\end{tabular}

Table 6. Interpretation of test items

\subsection{Improvement in Critical Thinking and Mathematical Representation Abilities}

Improvement in critical thinking and mathematical representation abilities can be seen in the students' test result before and after they were given treatment using MIKIMOM and PPT. The test result was then analyzed for statistic prerequisite to see the normality, homogeneity, and correlation before the statistical analysis.

Based on the result of the normality test, all of the data from the population are normally distributed. All of the data are on the value of .sig $>0.05$ in the column of Shapiro-Wilk in Table 7.

\begin{tabular}{|l|l|r|r|r|}
\hline \multirow{4}{*}{ Class } & \multicolumn{1}{|c|}{ Ability } & \multicolumn{3}{|c|}{ Shapiro-Wilk } \\
\cline { 3 - 5 } Experimental & \multicolumn{1}{|c|}{ Statistic } & \multicolumn{1}{c|}{ Df } & \multicolumn{1}{c|}{ Sig. } \\
\cline { 2 - 5 } & Critical thinking Pretest & 0.153 & 32 & 0.061 \\
\cline { 2 - 5 } & Mathematics Pretest & 0.144 & 32 & 0.074 \\
\cline { 2 - 5 } & Critical thinking Posttest & 0.149 & 32 & 0.078 \\
\cline { 2 - 5 } & Mathematics Posttest & 0.149 & 32 & 0.075 \\
\hline Control & Critical thinking Pretest & 0.152 & 32 & 0.209 \\
\cline { 2 - 5 } & Mathematics Pretest & 0.163 & 32 & 0.060 \\
\cline { 2 - 5 } & Critical thinking Posttest & 0.156 & 32 & 0.189 \\
\cline { 2 - 5 } & Mathematics Posttest & 0.150 & 32 & 0.195 \\
\hline
\end{tabular}

Table 7. Result of normality test 
The data are not only normally distributed, but also homogeneous. This is shown by the value of .sig 0.254 in Table 8. This value is $>0.05$ and thus it can be said that there is no variant difference between the control class and the experimental class so that the data are homogeneous.

The value of sig. (2-tailed) in Table 9 is 0.000 , which is $<0.05$. Therefore, it can be said that there is a relationship between mathematical representation and critical thinking abilities. Pearson correlation coefficient is 0.554 , which lies between 0.40 and 0.599 and thus the relationship between the two variables is quite strong.

The prerequisite analyses were followed by the analyses of the improvement and effectiveness of the use of comics. The result of the statistical test of MANOVA on Hotteling's Trace shows that the value of sig is 0.000 , which is lower than 0.05 .

Therefore, it can be said that there is a significant difference in the average score of the improvement of critical thinking and mathematical representation abilities between the class taught by using the MIKIMOM and that taught by using PPT. The improvement in the critical thinking and mathematical representation abilities can be seen in Table 11 and 12 .

\begin{tabular}{|l|r|}
\hline \multicolumn{2}{|c|}{ Box's test of equality of covariance matrices } \\
\hline Box's M & 4.220 \\
\hline F & 1.357 \\
\hline df1 & 3 \\
\hline df2 & 691920.000 \\
\hline Sig. & 0.254 \\
\hline
\end{tabular}

Table 8. Result of homogeneity test

\begin{tabular}{|c|c|c|c|}
\hline \multicolumn{2}{|c|}{ Correlation } & Mathematical representation & Critical thinking \\
\hline \multirow{3}{*}{$\begin{array}{l}\text { Mathematical } \\
\text { representation }\end{array}$} & Pearson Correlations & 1 & 0.554 \\
\hline & Sig. (2-tailed) & & 0.000 \\
\hline & $\mathrm{N}$ & 64 & 64 \\
\hline \multirow{3}{*}{ Critical thinking } & Pearson Correlations & 0.554 & 1 \\
\hline & Sig. (2-tailed) & 0.000 & \\
\hline & $\mathrm{N}$ & 64 & 64 \\
\hline
\end{tabular}

Table 9. Result of correlation test

\begin{tabular}{|c|r|r|}
\hline Effect & Value & \multicolumn{1}{c|}{ Sig. } \\
\hline Hotelling's Trace & & 0.321 \\
\hline
\end{tabular}

Table 10. Result of MANOVA

\begin{tabular}{|c|c|r|r|r|r|c|}
\hline No & Class & \multicolumn{1}{c|}{$\begin{array}{c}\text { Number } \\
\text { of students }\end{array}$} & $\begin{array}{c}\text { Average } \\
\text { of pretest }\end{array}$ & $\begin{array}{c}\text { Average } \\
\text { of postest }\end{array}$ & $\begin{array}{c}\text { Average } \\
\text { of gain score }\end{array}$ & Category \\
\hline 1 & Eksperimental & 32 & 28.13 & 80.86 & 0.73 & High \\
\hline 2 & Control & 32 & 30.47 & 69.53 & 0.56 & Medium \\
\hline
\end{tabular}

Table 11. Result of improvement in critical thinking abilities

\begin{tabular}{|c|c|r|r|r|r|c|}
\hline No & Class & \multicolumn{1}{|c|}{$\begin{array}{c}\text { Number } \\
\text { of students }\end{array}$} & $\begin{array}{c}\text { Average } \\
\text { of pretest }\end{array}$ & $\begin{array}{c}\text { Average } \\
\text { of postest }\end{array}$ & $\begin{array}{c}\text { Average } \\
\text { of gain score }\end{array}$ & Category \\
\hline 1 & Eksperimental & 32 & 32.42 & 86.13 & 0.79 & High \\
\hline 2 & Control & 32 & 25.98 & 70.31 & 0.61 & Medium \\
\hline
\end{tabular}

Table 12. Result of improvement in mathematical representation abilities 


\begin{tabular}{|c|c|r|r|c|}
\hline No & Variable & Eta square & Cohen's $\mathbf{f}$ & Interpretation \\
\hline 1 & Critical thinking & 0.179 & 0.197 & Medium Effect Size \\
\hline 2 & Mathematical representation & 0.287 & 0.339 & Large Effect Size \\
\hline
\end{tabular}

Table 13. Result of analysis of effect size

Table 11 and 12 shows that both the critical thinking ability and mathematical representation ability are in the high category in the experimental class. The comic media is effective in improving critical thinking and mathematical representation abilities. The effect size can be seen in the result of the analysis of effect size in Table 13. Column Eta Square shows the scores of 0.287 (large effect size) and 0.179 (medium effect size). Therefore, it can be said that MIKIMOM is effective in improving critical thinking and mathematical representation abilities with the medium and large effect size.

Table 13 has similarity with the research by (Sari, Nikmah, Kuswanto \& Wardani, 2020) which reported that the teaching by using a comic integrated to traditional games or local wisdom was effective and could improve students' mathematical representation ability. The research by (Azmy, Kuswanto \& Susetyo, 2020) also reported that teaching by using comic media could improve students' critical thinking ability.

Table 13 shows that there is a difference in the improvement both the critical thinking ability and mathematical representation ability of the experimental class and control class. This shows that the experimental class which used the MIKIMOM is better at the improvement in critical thinking and mathematical representation abilities compared to the conventional class. One of the factors affecting this is the characteristic of the media. The comic media contains the teaching of mathematical representation which facilitates students to understand a certain concept (Supandi et al., 2018) and solve problems by using their reasoning skill (Nor'ain Mohd \& Chinnappan, 2016). It contains indicators of critical thinking which can encourage students to reason, discuss, and draw conclusions by themselves (Viennot \& Nicolas, 2018) which results in their high academic achievement (Alessio, Avolio \& Charles, 2019). In addition, the media refers to learning everyday life phenomena such as carom games, so that critical thinking ability can be improved (Yuliati et al., 2018). Comic media is also integrated to discovery learning, the teaching model which can stimulate and facilitate students to think critically (Anggraini, Murni \& Sakur, 2018; Sulistiani et al., 2018) and help improve mathematical representation ability (Minarni et al., 2016; Ertikanto, Rosidin, Distrik, Yuberti \& Rahay 2018).

The MIKIMOM enables students to learn individually because it contains the steps of discovery learning. Students can learn at anytime and anywhere. They can understand the learning materials easily because the materials are related to everyday life phenomena in carom games. The simple colloquial language makes students not easily get bored of reading the comic materials and content. In addition, students can stimulate critical thinking and mathematical representation abilities through the conversation among the characters in the comic, which contains indicators of critical thinking and mathematical representation abilities. These two abilities can also be improved by doing discussion items in the comic and then evaluating the abilities from the available discussion. 

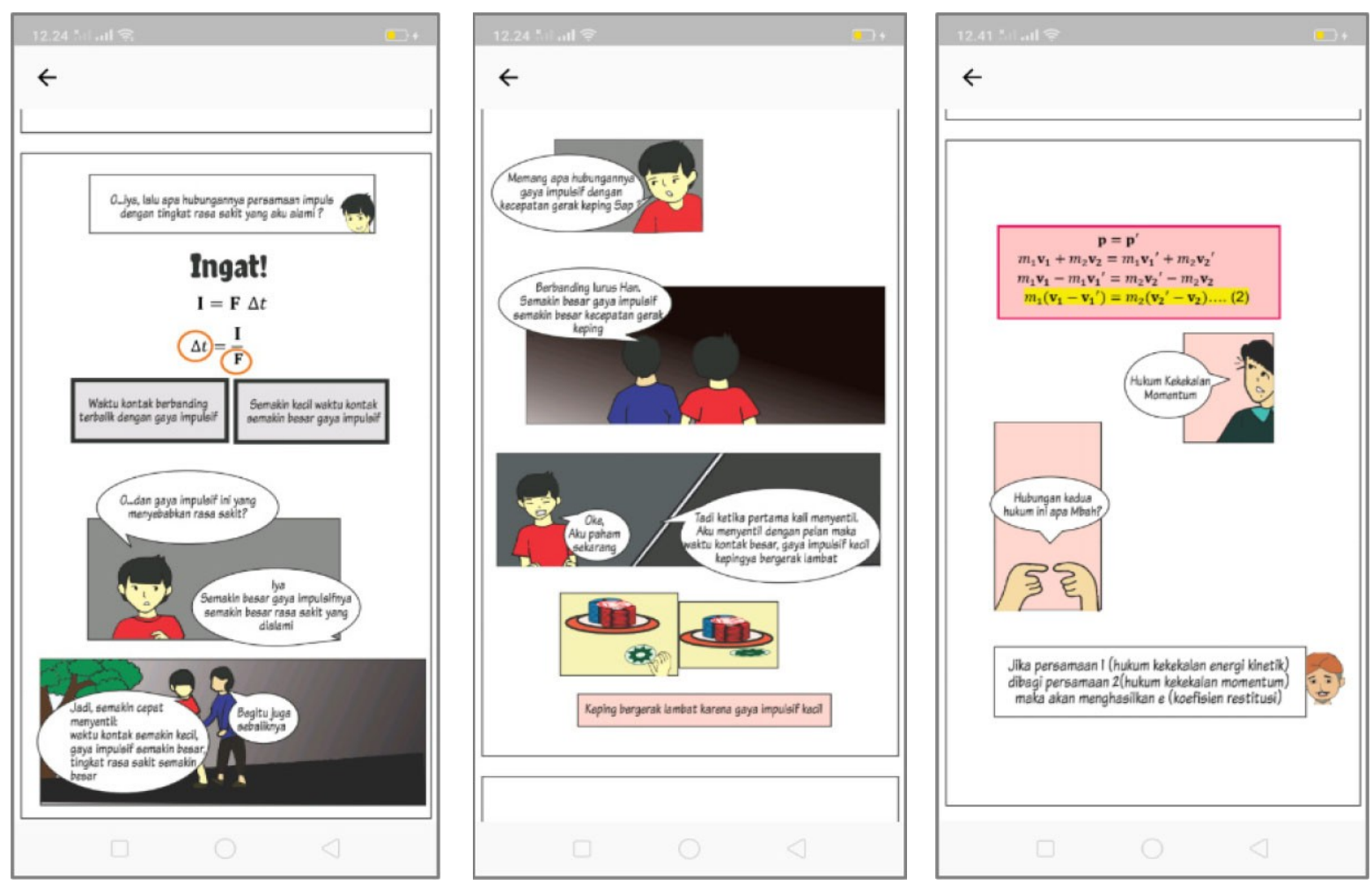

Figure 5. The comic containing indicators of critical thinking and mathematical representation abilities
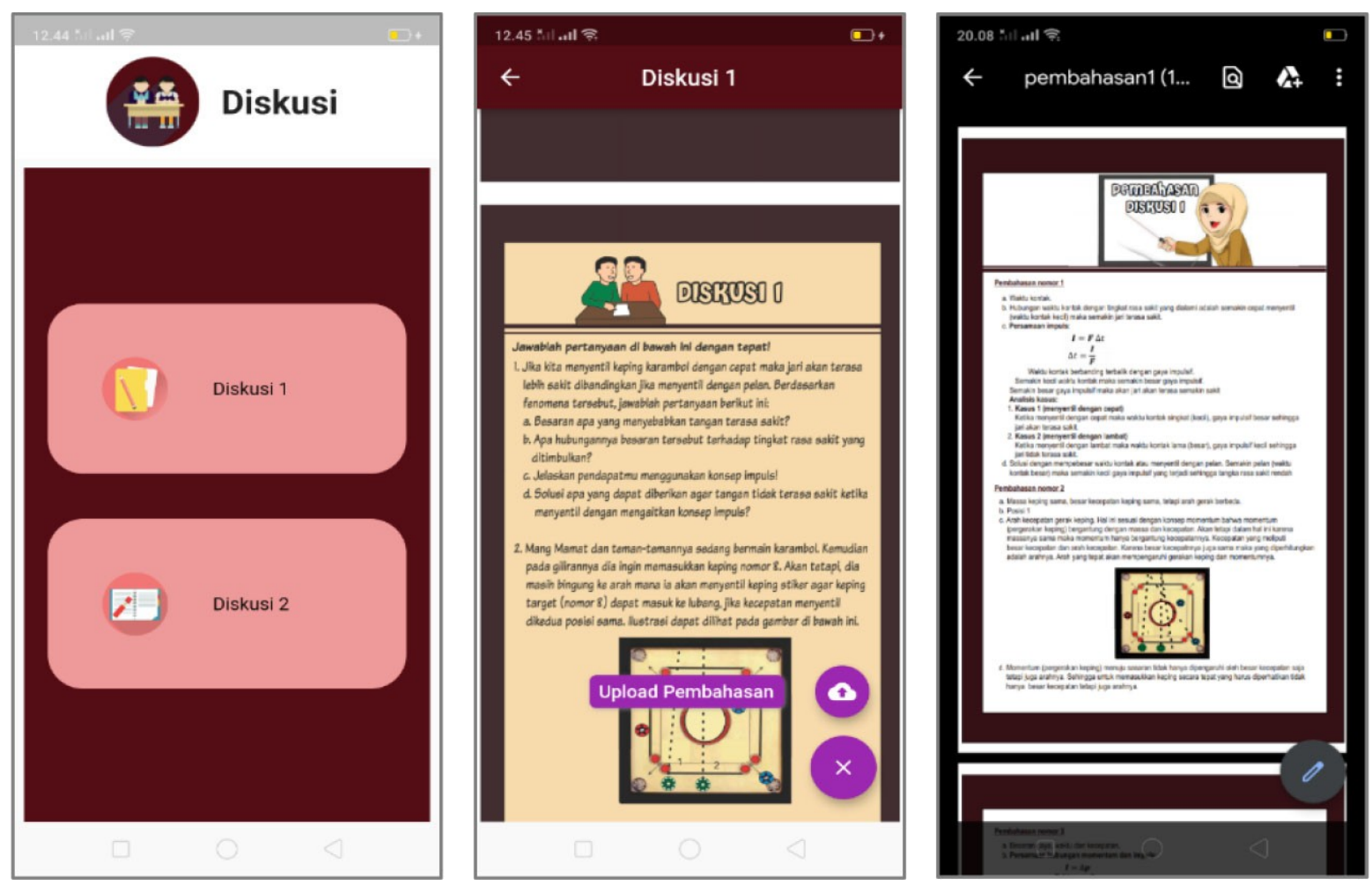

Figure 6. Discussion items containing indicators of critical thinking and mathematical representation abilities

\section{Conclusion}

The improvement in both the critical thinking ability and mathematical representation ability of the experimental class, which used the Android-based carom game comic integrated to discovery learning, is higher than that of the control class which used the power points (PPT). The Android-based carom game 
comic integrated to discovery learning is effective in improving the students' critical thinking and mathematical representation abilities in physics teaching, with the scores of 0.287 (large effect size) and 0.179 (medium effect size). The Android-based carom game comic integrated to discovery learning can be used as an alternative in choosing teaching media for improving critical thinking and mathematical representation abilities.

\section{Declaration of Conflicting Interests}

The authors declared no potential conflicts of interest with respect to the research, authorship, and/or publication of this article.

\section{Funding}

The research was supported by the Ministry of Research and Technology and the National Research and Innovation Agency of the Republic Indonesia for funding this research through the Master Thesis Research Scheme (PTM) by contract number 058/SP2H/LT/DRPM/2020 and T/9.72/UN34.21/PT.01.03/2020 and the Institute for Research and Community Service (LPPM).

\section{References}

Adam, R.J., \& Kho, S.T. (1996). Acer quest version 2.1. Camberwell, The Australian Council for Education Research: Victoria.

Alessio, F.A.D., Avolio, B.E., \& Charles, V. (2019). Studying the impact of critical thinking on the academic performance of executive MBA students. Thinking Skills and Creativity, 31(1), 275-283. https://doi.org/10.1016/j.tsc.2019.02.002

Anggraini, R.D., Murni, A., \& Sakur. (2018). Differences in students' learning outcome s between discovery learning and conventional learning models. In The 6th South East Asia Design Research International Conference (6th SEA-DR IC) (1-5). https://doi.org/10.1088/1742-6596/1088/1/012070

Asisningtyas, Y., \& Suryanti. (2017). Pengaruh penggunaan media karambol terhadap hasil belajar materi gaya siswa kelas V SD. Jurnal Penelitian Pendidikan Guru Sekolab Dasar, 5(3), 130-137. https://jurnalmahasiswa.unesa.ac.id/index.php/jurnal-penelitian-pgsd/article/view/20158

Atmaja, B.T., Jonemaro, E.M.A., \& Arwani, I. (2017). Pengembangan game karambol pada interactive projected display. Jurnal Pengembangan Teknologi Informasi dan Ilmu Komputer, 1(9), $739-747$.

Azmy, W.N., Kuswanto, H., \& Susetyo, R. (2020). Learning optics with android-assisted comics: The impacts on students critical thinking. Journal of Physics: Conference Series, 1440, 1-7. https://doi.org/10.1088/1742-6596/1440/1/012055

Bego, C.R., Chastain, R.J., Pyles, L.M., \& DeCaro, M.S. (2018). Multiple representations in physics: deliberate practice does not improve exam scores. Proceedings of the IEEE Frontiers in Education conference. https://doi.org/10.1109/FIE.2018.8658730

Budiarti, A., Rusnayati, H., Siahaan, P., \& Wijaya, A.F.C. (2018). Profil hambatan belajar epistimologis siswa pada materi momentum dan impuls kelas X SMA berbasis analisis tes kemampuan responden. Jurnal Wahana Pendidikan Fisika, 3(1), 35-42. https://doi.org/10.17509/wapfi.v3i1.10936

Cahyono, A., Isnandar, \& Usodo, B. (2019). Implementation of mathematical comic on exponent and logarithms with 21 st century skills - oriented. Journal of Physics: Conference Series, 1211, 1-7. https://doi.org/10.1088/1742-6596/1211/1/012078

Cartrette, D.P., \& Bodner, G.M. (2010). Non-mathematical problem solving in organic chemistry. Journal of Research in Science Teaching, 47(6), 643-660. https://doi.org/10.1002/tea.20306

Cohen, J. (1988). Statistical Power Analysis for Behavioral Science (2nd ed.). Hillsdale, N.J.: Erlbaum Associates. 
Doran, Y.J. (2017). The role of mathematics in physics: Building knowledge and describing the empirical world. ONOMAZEIN - Número Especial SFL TCL Sobre Educación Conocimiento: 209-226.

https://doi.org/10.7764/onomazein.sfl.08

Docktor, J.L., \& Mestre, J.P. (2014). Synthesis of discipline-based education research in physics. Physical Review Special Topics-Physics Education Research, 020119, 1-58.

https://doi.org/10.1103/PhysRevSTPER.10.020119

El Soufi, N., \& See, B.H. (2019). Does explicit teaching of critical thinking improve critical thinking skills of English language learners in higher education? A critical review of causal evidence. Studies in Educational Evaluation, 60(1), 140-162. https://doi.org/10.1016/j.stueduc.2018.12.006

Ertikanto, C., Rosidin, U., Distrik, W., Yuberti, \& Rahayu, T. (2018). Comparison of mathematical representation skills and science learning result in classes with problem based and discovery learning model. Jurnal Pendidikan IPA Indonesia, 7(1), 106-113. https://doi.org/10.15294/jpii.v6i2.9512

Guérin, C., Rigaud, C., Bertet, K., \& Revel, A. (2017). An ontology-based framework for the automated analysis and interpretation of comic books' images. Information Sciences, 378, 109-130.

https://doi.org/10.1016/j.ins.2016.10.032

Hambleton, R.K., Swaminathan, H., \& Rogers, H.J. (1991). Fundamental of Item Response Theory. Sage Publications: Newbury Park.

Hau, R.R.H., Marwoto, P., \& Putra, N.M.D. (2018). Pattern of mathematic representation ability in magnetic electricity problem. International Conference on Mathematics, Science and Education 2017 (ICMSE2017), 983(1). https://doi.org/10.1088/1742-6596/983/1/012015

Hosnan, M. (2014). Pendekatan saintifik dan kontekstual dalam pembelajaran abad 21. Bogor: Ghalia Indonesia.

In'am, A., \& Hajar, S. (2017). Learning geometry through discovery learning using a scientific approach. International Journal of Instruction, 10(1), 55-70. https://doi.org/10.12973/iji.2017.1014a

Irwandani, I., \& Juariah, S. (2016). Pengembangan media pembelajaran berupa komik fisika berbantuan sosial media instagram sebagai alternatif pembelajaran. Jurnal Ilmiah Pendidikan Fisika Al-BiRuNi, 05(1), 33-42. https://doi.org/10.24042/jpifalbiruni.v5i1.103

Isnaningsih, \& Bimo, D.S. (2013). Penerapan lembar kegiatan siswa (LKS) discovery learning berorientasi keterampilan proses sains untuk meningkatkan hasil belajar IPA. Jurnal Pendidikan IPA Indonesia, 2(2), 136-141. https://journal.unnes.ac.id/nju/index.php/ipii/article/view/2714/2789

Jaccard, J., \& Jacoby, J. (2010). Theory contruction and model-building skills. New York: Guilfrord Press.

Jitendra, A.K., Nelson, G., Pulles, S.M., Kiss, A.J., \& Houseworth, J. (2016). Is mathematical representation of problems an evidence-based strategy for students with mathematics difficulties? Exceptional Childern, 245, 1-18. https://doi.org/10.1177/0014402915625062

Karim, S., Saepuzaman, D., \& Sriyansyah, S.P. (2015). Diagnosis kesulitan belajar mahasiswa dalam memahami konsep momentum. Jurnal Penelitian \& Pengembangan Pendidikan Fisika, 1(1), 85-90. https://doi.org/10.21009/1.01112

Kuo, E., Hull, M.M., Gupta, A., \& Elby, A. (2012). How students blend conceptual and formal mathematical reasoning in solving physics problems. Sciences Education, 91(1), 32-57.

https://doi.org/10.1002/sce.21043

Maghfiroh, A., Kuswanto, H., \& Susetyo, B. (2020). The development of android-based physics comic on optical devices for high school students. Journal of Physics: Conference Series, 1440, 1-6.

https://doi.org/10.1088/1742-6596/1440/1/012023 
Martaida, T., Bukit, N., \& Ginting, E.M. (2017). The effect of discovery learning model on student's critical thinking and cognitive ability in Junior High School. IOSR Journal of Research \& Method in Education, 7(6), 1-8. https://doi.org/10.9790/7388-0706010108

Meltzer, E.D. (2002). The relationship between mathematics preparation and conceptual learning gains in physics: a possible "bidden variable" in diagnostic pretest scores. Departement of Physics and Astronomy, Lowa State University Journal. https://doi.org/10.1119/1.1514215

Minarni, A., Napitupulu, E.E., \& Husein, R. (2016). Mathematical understanding and representation ability of public Junior High School in North Sumatra. Journal on Mathematics Education, 7(1), 43-56. https://doi.org/10.22342/jme.7.1.2816.43-56

Mutia, D.I., Gani, A., \& Syukri, M. (2020). The influences of comics' media application in students' scientific perspectives attitude. IOP Conf. Series: Journal of Physics: Conference Series, 1460. 1-5. https://doi.org/10.1088/1742-6596/1460/1/012130

Namdar, B., \& Shen, J. (2017). Knowledge organization through multiple representations in a computer-supported collaborative learning environment. Interactive Learning Environments, 26, 1-16. https://doi.org/10.1080/10494820.2017.1376337

Nikmah, S., Haroky, F., Jumadi, Wilujeng, I., \& Kuswanto, H. (2019). Development of android comic media for the chapter of Newton's Gravity to map learning motivation of students. Journal of Physics: Conference Series, 1233, 1-10. https://doi.org/10.1088/1742-6596/1233/1/012051

Nor'ain Mohd, T., \& Chinnappan, M. (2016). The link between Higher Order Thinking Skills, representation and concepts in enhancing TIMSS tasks. Intenational Journal of Instruction, 9(2), 200-2014. https://doi.org/10.12973/iji.2016.9214a

Park, E.-J., \& Choi, K. (2013). Analysis of student understanding of science concepts including mathematical representations: ph values and the relative differences of ph values. International Journal of Science and Mathematics Education, 11(6), 683-706. https://link.springer.com/article/10.1007/s10763-012-9359-7

Permatasari, D.R., Soegiyanto, H., \& Usodo, B. (2019). The use of discovery learning model with RME approach viewed from interpersonal intelligence. Journal of Education and Learning, 13(1), 87-92. https://doi.org/10.11591/edulearn.v13i1.8414

Purwadi, I.M.A., Sudiarta, I.G.P., \& Suparta, I.N. (2019). The effect of concrete-pictorial-abstract strategy toward students' mathematical representation on fractions. International Journal of Instruction, 12(1), 1113-1126. http://www.e-iii.net/volumes/353-january-2019,-volume-12.-number-1 https://doi.org/10.29333/iji.2019.12171a

Puspita, P., Kaniawati, I., \& Suwarma, I.R. (2017). Analysis of critical thinking skills on the topic of static fluid. International Conference on Mathematics and Science Education (ICMScE), 895, 1-7. https://iopscience.iop.org/article/10.1088/1742-6596/895/1/012100

Priyadi, A.N.W., Kuswanto, H., \& Sumarna. (2020). Android physics comics to train the mathematical representation ability on momentum and impulse of senior high school students. In The 5th International Seminar on Science Education. https://doi.org/10.1088/1742-6596/1440/1/012041

Rahayu, M.S.I., \& Kuswanto, H. (2020). Development of android-based comics integrated with scientific approach in physics learning. Journal of Physics: Conference Series, 1440. 1-8. https://doi.org/10.1088/1742-6596/1440/1/012040

Ramdhani, M.R., Usodo, B., \& Subanti, S. (2017). Discovery learning with scientific approach on geometry. In International Conference on Mathematics and Science Education (ICMScE), 1-6. https://doi.org/10.1088/1742-6596/895/1/012033 
Raras, M, \& Kuswanto, H. (2019). Developing Jemparingan Tradition-Based and AndroidAssisted Learning Media for Improving the Graphic and Vector Representation Ability. International Journal of Interactive Mobile Technologies (iJIM), 13(5), 58-74. https://doi.org/10.3991/ijim.v13i05.9926

Redish, E.F., \& Kuo, E. (2015). Language of physics, language of math: disciplinary culture and dynamic epistemology. Science \& Education, 24, 561-590. https://doi.org/10.1007/s11191-015-9749-7

Rina, N. (2020). Character education based on digital comic media. International Journal of Interactive Mobile Technologies (jIIM), 14(3), 107-127. https://doi.org/10.3991/ijim.v14i03.12111

Sari, D.P., Dahrim, \& Rosjanuardi, R. (2018). Errors of students learning with react strategy in solving the problems of mathematical. Journal on Mathematics Education, 9(1), 121-128. https://ejournal.unsri.ac.id/index.php/ime/article/view/4301 https://doi.org/10.22342/jme.9.1.4378.121-128

Sari, F.P., Nikmah, S., Kuswanto, H., \& Wardani, R. (2020). Development of physics comic based on local wisdom: Hopscotch (engklek) game android-assisted to improve mathematical representation ability and creative thinking of high school students. Revista Mexicana de Fisica E, 17(2), 255-262.

https://doi.org/10.31349/RevMexFisE.17.255

Siswanto, J., Susantini, E., \& Jatmiko, B. (2012). Practicality and effectiveness of the IMBR teaching model to improve physics problem solving skills. Journal of Baltic Science Education, 17(3), 381-394. http://oaji.net/articles/2017/987-1529508735.pdf https://doi.org/10.33225/jbse/18.17.381

Sulistiani, E., Waluya, S.B., \& Masrukan. (2018). The analysis of student's critical thinking ability on discovery learning by using hand on activity based on the curiosity. In International Conference on Mathematics, Science and Education 2017 (ICMSE2017) (1-7). https://doi.org/10.1088/1742-6596/983/1/012134

Supandi, S., Waluya, S.B., Rochmad, R., Suyitno, H., \& Dewi, K. (2018). Think-Talk-Write model for improving students' abilities in mathematical representation. International Journal of Instruction, 11(3), 77-90. http://www.e-iji.net/volumes/351-july-2018,-volume-11.-number-3

https://doi.org/10.12973/iji.2018.1136a

Sutrisno, F.H., Handayanto, S.K., Supriyana, E., \& Laksmisari, R. (2018). How does the students' critical thinking ability in geometry optics. Unnes Science Education Journal, 7(2), 186-191.

https://doi.org/10.15294/usej.v7i2.24297

Viennot, L., \& Nicolas, D. (2018). Activation of a critical attitude in prospective teachers: From research investigations to guidelines for teacher education. Physical Review Physics Education Research, 010133, 1-19. https://doi.org/10.1103/PhysRevPhysEducRes.14.010133

Wahyudi, Verawati, N.N.S.P., Ayub, S., \& Prayogi, S. (2019). The effect of scientific creativity in inquiry learning to promote critical thinking ability of prospective teachers. International Journal of Emerging Technologies in Learning (iJET), 14(14), 122. https://doi.org/10.3991/ijet.v14i14.9532

Yuliati, L., Fauziah, R., \& Hidayat, A. (2018). Student's critical thinking skills in authentic problem based learning. 4th International Seminar of Mathematics, Science and Computer Science Education, 1013, 1-9. https://doi.org/10.1088/1742-6596/1013/1/012025

Published by OmniaScience (www.omniascience.com) Journal of Technology and Science Education, 2021 (www.jotse.org)

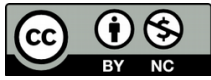

Article's contents are provided on an Attribution-Non Commercial 4.0 Creative commons International License. Readers are allowed to copy, distribute and communicate article's contents, provided the author's and JOTSE journal's names are included. It must not be used for commercial purposes. To see the complete licence contents, please visit https://creativecommons.org/licenses/by-nc/4.0/. 